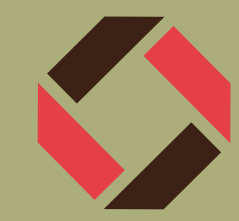

\title{
You're so hip, darling: Materials researchers do stand-up comedy
}

\author{
@BrightClubGLA @BrightClubEDN
}

"I was once asked what kind of music stem cells would like best. Classical, I decided, because they're $\mathrm{cul}$ tured." This was just one in a string of tales Laura McNamara unraveled at the debut Glasgow Bright Club a few years ago, where science meets humor.

Bright Club, which is a comedyclub-style event featuring scientists and academics, started in England at University College London before migrating to many cities across the United Kingdom. Academics brave the spotlight to vent about anything, from Greek mythology to neuroscience to "Booze Britain" culture. The eclectic shows have been met by enthusiastic audiences and media coverage, including The Guardian, "If you dig science and fancy laughing while learning, check

\section{Behind the Scenes: Bright Club Edinburgh} out Bright Club"

The Skinny

\section{by Dan Ridley-Ellis}

I never had an ambition to be a comedian and still don't, but I'm very glad this didn't stop me from trying it. Why, and how, I'd agreed to doing it in the first place I don't quite recall, but I do remember my initial doubts fading as the date of Bright Club Edinburgh's debut show approached. Our little gang of

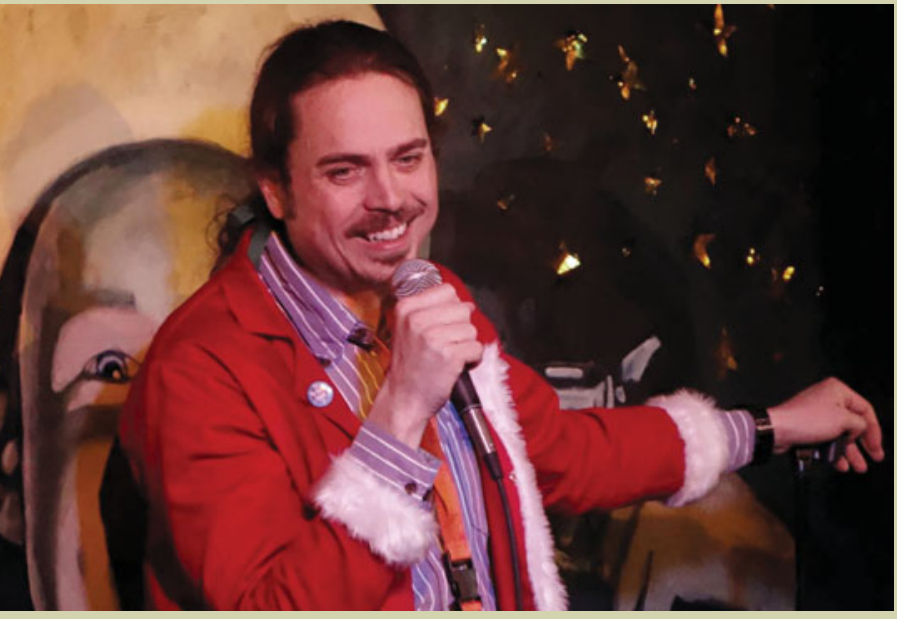
performers was mutually supportive, fun to be with, and being enthusiastically coached by professional comedian Susan Morrison.

I've done plenty of public speaking, but this was still new and frightening. Stand-up makes demands that research presentations don't. Most obviously, there is no security blanket of PowerPoint, and comedy requires a certain sequence and rhythm to work. The audience is both more engaged and more distracted and is, of course, non-specialist - except in knowing what they find funny. The format of Bright Club allows you to be interesting in the gaps between punch lines but the real challenge lies in finding the line between just being funny, with the audience not learning anything, and making the audience think so much that they forget to laugh.

And it's laughs you want - no other form of audience feedback is so immediate and rewarding. I've never given a research presentation and then immediately felt an urge to do it again. Professional comedians talk about being on stage as being like an addiction, and now I understand what they mean. I enjoyed it so much I decided to help make sure Bright Club Edinburgh continues with regular shows - even to the point of doing a full run at the Edinburgh Fringe in 2013 with a crew of 90 researchers and other specialists from across the UK. Not only is it the most fun way to meet other researchers, but it's also got enormous benefits for personal development — even for experienced researchers. described Bright Club as "the epitome of smart meets funny."

Researchers who perform at Bright Club span all ages, career levels, and disciplines. McNamara, who was culturing stem cells on nanopatterned titanium surfaces in her postdoctoral work at the time of her first stand-up routine, is now the science education coordinator at the Glasgow Science Centre. Another Bright Club colleague, Dan Ridley-Ellis, researches the mechanical properties of timber at Edinburgh Napier University. They, along with other Bright Clubbers, discover untapped reserves of confidence and potential, and use it as a springboard to bigger things - but this is not about becoming famous, or becoming a comedian. It is about having fun, and about researchers telling people a little about what they do and why they find it so engaging.

Bright Club events typically involve six researchers each doing about eight minutes of stand-up comedy about their own field in front of a paying audience who turn up to be entertained by a blend of jokes and interesting information. Shows have a professional comedian compere and set everything up to make it as easy as possible for the researchers, the majority of whom have never done comedy before. Bright Clubs usually provide some form of training to help with writing and performance in the lead up to a show, and the audiences are friendly and encouraging. Bright Club is akin to doing a departmental research seminar prior to an international conference: a safe, supportive environment in which to get useful experience. 
Everybody has a sense of humor-at least in theory. What makes comedians different is that they spend time thinking about how humor works, how it can be improved, and how it can be stretched into new shapes. Humor lies in looking at activities from new angles, making connections between ideas that were previously unconnected, in an obsession with details, in challenging opinions to their limits, and in playing with words and their meanings.

The world of the researcher and the world of stand-up comedy have a lot in common, but comedians and researchers have very different approaches to preparation and communication. Even academics experienced in public speaking or teaching can learn something valuable from the world of stand-up that could enhance their university work including teaching, presentations, public engagement, and media activities.

So how exactly do researchers do stand-up comedy about their work without appearing to devalue it, oversimplify, bend the truth, provoke controversy, or die on stage? People approach this in different ways, but one way is to treat it primarily as a public engagement exercise. The recipe is to choose one message, break it down into three or four elements, and then start to think of funny things to link between those.

McNamara-aka "Hip-ster"—was culturing stem cells with the aim of improving hip replacements during the time of her first stand-up routine. In finding a way to help a non-specialist audience understand her work, McNamara personified the materials involved:

I work with a strong, silent character named Titanium. He's a pretty hunky metal, sandwiched somewhere in the periodic table between the element of surprise and his more volatile

\section{Behind the Scenes: Bright Club Glasgow}

\section{y Laura MeNamara}

I heard about Bright Club when my friend Zara performed at the first Edinburgh show. I was used

to speaking about research, and I've always loved comedy, but until Zara brought Bright Club to Glasgow and asked if I would like to perform at the debut sh, I didn't think that I would ever take the plunge to try

After writing sc

fter writing screeds of material (most of which ended Bright Clubbers. Our first rehearsal was a bit daunting, but the group was very supportive, and we gave each other feedback that helped us redraft our sets.

After another rehearsal, we had a final run-through in the only another 20 reserved for door sales. I had been really ut this, but was getting more nervous waiting to begin - I got a fright when I suddenly ad a mental block and couldn't remember half of my et! Fortunately, the nerves melted away when I got

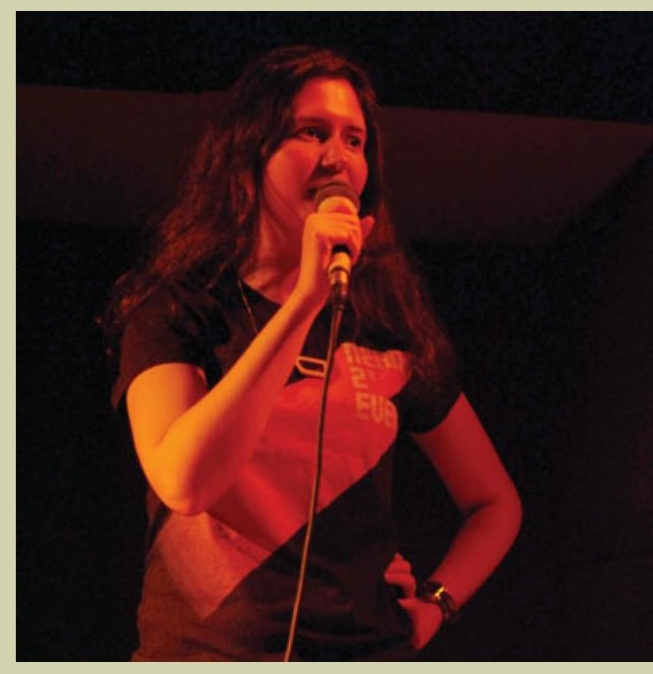
on stage - it was such a great feeling each time the

audience laughed. I had fun, especially when I had the chance to ad-lib with the audience, and it was really encouraging to hear their lovely, and often amusing, feedback. Someone even told me they thought I had "great tibia," in reference to my skeleton-print tights! Performing at Bright Club has genuinely helped me to improve my presentation and engagement skills for teaching and conference talks; I have more confidence undertaking other public engagement activities, and I felt it was a valuable and distinctive way of sharing research with the wider world. I would highly recommend it to other researchers-it is a unique opportunity, and the memories are fab!

cousin,

the element

of danger. Danger's

pretty popular with the ladies. Not so much Titanium, though, poor guy. He seems a bit standoffish to stem cells ... but he was actually kinda hoping to meet someone special. Maybe a nice naïve stem cell that he could fall in love with and one day ... marrow.

From November 2011 performance

Personification was the option chosen by Ridley-Ellis, too, along with a traditional introduction:

So an English elm, a Welsh oak, and a Scots pine start growing in a bar. At this point, you're probably wondering where l'm going with my tree-based nationalism because I don't appear to be Scottish and yet here we are in Edinburgh. It seems a bit risky, doesn't it? Well, the truth is, I don't know where this joke is going either because they're trees. We have to wait 30 or 40 years for the punchline ... See, that's the thing about trees; they take a while to grow. In some fields of forest research you can be retired by the time anyone finds out that you made a mistake. And if they find out sooner, well, forests are excellent places to hide a body.

From October 2012 performance

Of course comedy is all in the timing, which is missing from the page. Fortunately, social media abounds with YouTube clips, and Bright Clubs are plentiful across several UK cities and in Australia as well. To launch a Bright Club, all one needs is a friendly professional comedian willing to share some know-how, a few adventurous researchers, and a venue. 


\section{MRS ENERGY $\infty$ SUSTAINABILJTYY A Review Journal}

\section{MRS ENERGY OS SUSTAINABILITY}

A Review Journal

\section{Key Topics Recently Published}

Emerging trends in bioenergy harvesters for chronic powered implants

Tushar Sharma, Intel Corporation, USA; Sahil Naik, The University of Texas at Austin, USA; Ashwini Gopal, Nanoshift LLC, USA; and John X.J. Zhang, Dartmouth College, USA

Understanding dynamic availability risk of critical materials:

The role and evolution of market analysis and modeling

Elsa Olivetti, Frank Field, and Randolph Kirchain, Massachusetts Institute of Technology, USA

A review of water and greenhouse gas impacts of unconventional natural gas

development in the United States

Douglas J. Arent, Jeffrey Logan, Jordan Macknick, Garvin Heath, Patricia Statwick,

National Renewable Energy Laboratory, USA; William Boyd, University of Colorado Law School,

USA; Kenneth Medlock III, Rice University, USA; Francis O'Sullivan, Massachusetts Institute

of Technology, USA; Jae Edmonds, Leon Clarke, Pacific Northwest National Laboratory, USA;

Hillard Huntington, Stanford University, USA; and Morgan Bazilian, Columbia University, USA

Recent results on the integration of renewable electric power into the US grid

Jay Apt, Carnegie Mellon University, USA

A review on direct methanol fuel cells from the perspective of energy and sustainability Prabhuram Joghee, Jennifer Nekuda Malik, Svitlana Pylypenko, and Ryan O'Hayre, Colorado School of Mines, USA

Energy availability and energy sources as determinants of societal development in a long-term perspective

Marina Fischer-Kowalski and Anke Schaffartzik, Alpen-Adria University

Klagenfurt-Wien-Graz, Austria

Laser processing of materials for renewable energy applications

Mool C. Gupta, University of Virginia, USA; and David E. Carlson, BP Solar, USA

Solid-state lighting with wide band gap semiconductors

Faiz Rahman, Ohio University, USA

Surface engineering for phase change heat transfer: A review

Daniel Attinger, Christophe Frankiewicz, lowa State University, USA; Amy Rachel Betz,

Kansas State University, USA; Constantine Megaridis, Thomas Schutzius, Arindam Das, University of Illinois at Chicago, USA; Ranjan Ganguly, Jadavpur University, India; and

Chang-Jin Kim, University of California, Los Angeles, USA

From highly graphitic to amorphous carbon dots: A critical review

Antonios Kelarakis, University of Central Lancashire, United Kingdom

The rectenna device: From theory to practice (a review)

Evgeniy Donchev, Jing Sheng Pang, Peter K. Petrov, Neil M. Alford, Imperial College London, United Kingdom; and Peter M. Gammon,

University of Warwick, United Kingdom

Concerning the global-scale introduction of renewable energies:

Technical and economic challenges

David Faiman, Ben-Gurion University of the Negev, Israel
SUBMIT YOUR PROPOSAL TODAY.

For more information, including author benefits, open access options, indexing and proposal form, visit www.mrs.org/energy-sustainability-journal.

\section{EDITORS-IN-CHIEF}

David S. Ginley

National Renewable Energy Laboratory, USA

\section{David Cahen}

Weizmann Institute of Science, Israel

\section{Sally M. Benson}

Stanford University, USA

\section{CHAIR, ADVISORY BOARD}

Alan J. Hurd

Los Alamos National Laboratory, USA

MRS Energy \& Sustainability—A Review Journal publishes reviews on key topics in materials research and development as they relate to energy and sustainability. Review topics include new R\&D of both established and new areas; systems integration; and objective application of economic, sociological and governmental models, enabling research and technological developments. The reviews are set in an integrated context of scientific, technological and sociological complexities relating to environment and sustainability.

The intended readership is a broad spectrum of scientists, academics, policy makers and industry professionals, all interested in the interdisciplinary nature of science, technology, and policy aspects of energy and sustainability.
Published jointly by the Materials Research Society and Cambridge University Press 